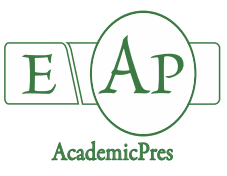

Mosavikia AA et al. (2020)

Notulae Botanicae Horti Agrobotanici Cluj-Napoca 48(1):221-233

DOI:10.15835/nbha48111777

Research Article

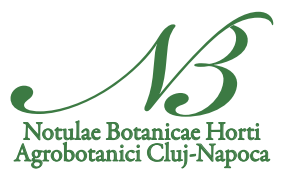

\title{
Chitosan nanoparticle and pyridoxine seed priming improves tolerance to salinity in milk thistle seedling [Silybum marianum (L.) Gaertn.]
}

\author{
Ali Asghar MOSAVIKIA, Seyed Gholamreza MOSAVI*, \\ Mohammadjavad SEGHATOLESLAMI, Reza BARADARAN
}

Islamic Azad University, Department of Agronomy,Birjand Branch, Birjand, Iran; mosavikia@yahoo.com;

s_mosavi25@yahoo.com_(*orrespondingauthor); seghatoleslami@yahoo.com; baradaran@yahoo.com

\begin{abstract}
Application of growth regulators plays important role under salt conditions. Perspectives to overcome these limitations by chitosan nanoparticle (CSNP: 0, 0.25, 0.5, and 1\%) and pyridoxine (PN: 0, 0.03, 0.06, and $0.09 \%)$ seed priming was studied in both experiments with milk thistle seeds exposed to $\mathrm{NaCl}$ as salt stress $(0$, 50,100 , and $150 \mathrm{mM}$ ). Salinity threshold and $\mathrm{EC}_{50}$ (the salinity level that $50 \%$ of germination reduction) achieved 74.85 and $213.5 \mathrm{mM}$, respectively. A significant reduction in germination percentage $(49.12 \%)$, seedling length (50.07\%), and seedling vigor index (67.39\%) while, a significant increase in superoxide dismutase activity $(54.63 \%)$ were achieved at $150 \mathrm{mM} \mathrm{NaCl}$ in compared to the control treatment. The highest germination rate was resulted by $100 \mathrm{mM} \mathrm{NaCl}$ and $0.25 \% \mathrm{CSNP}$ and the least $(2.86 \mathrm{seed} /$ day $)$ by $150 \mathrm{mM}$ $\mathrm{NaCl}$ and without CSNP. The salt stress significantly decreased photosynthetic pigments; however, the largest value of chlorophyll a, b, and total was related to without $\mathrm{NaCl}$ and $1 \%$ CSNP and the least value of traits (6.1, 1.67, and $7.77 \mu \mathrm{g} / \mathrm{g} \mathrm{FW}$ ) to non-application of CSNP under $150 \mathrm{mM} \mathrm{NaCl}$. PN application was caused decrease in free proline content compared to the non-application treatment. The most pronounced effects of CSNP and PN were recorded in 0.25 and $0.09 \%$ concentrations, respectively. The finding of this study leads to the conclusion that seed priming with CSNP and PN by improving physiological mechanisms such as photosynthetic pigment synthesis, antioxidant enzyme activities, and free proline content increased salt tolerance in milk thistle seedling.

Keywords: free proline content; photosynthetic pigments; salinity threshold; seed vigour index; sodium chloride

Abbreviations: CSNP, Chitosan nanoparticle; PN, Pyridoxine; GP, Germination percentage; GR, Germination rate; SVI, Seedling vigor index; MGT, Mean time germination; CAT, Catalase activity; SOD, Superoxide dismutase; LSD, least significant difference; Chl, Chlorophyll
\end{abstract}

\section{Introduction}

Milk thistle (Silybum marianum (L.) Gaertn.) medicinal plant belonging to the Asteraceae family. The plant grows natively in the Mediterranean and is well-known in other regions in the world such as Iran (Sedghi 
et al., 2010). Seeds are achenes and contain silymarin by characteristics $5-8 \mathrm{~mm}$ long and $28-30 \mathrm{~g} 1000$ seed weight (Rosinska et al., 2018).

Salt stress is one of the major reasons for plant production losses, by disorder plant growth (Lauchli and Luttge, 2012). Salinity damages related to the management applies, genotypes, and sensitivity of crop species (Farooq et al., 2015). Nutrient imbalance, ionic toxicity, and oxidative and/or osmotic stresses cause decreasing plant production (Imran et al., 2018). Salt stress conditions adversely affected seed germination as one of the most critical stages of plant growth (Ghavami and Ramin, 2007). Demonstrated that the salinity stress decrease germination percentage (GP) and germination rate (GR) of most crops (Ghoulam and Fares, 2001).

Priming is one of the important methods for the improvement of seed germination under salinity conditions. Seed priming as a pre-sowing technique can improve radicle emergence, GR, seedling vigour index (SVI), seedling establishment, and yield by making changes in metabolic activities in the seeds of many crops (Nasiri et al., 2014). The priming method by decreasing free radicals and Malondialdehyde production and increasing antioxidant activities was moderate the negative effects of stress condition (Parmoon et al., 2015). Vitamin B6 (PN) is a critical nutrient in the human regime and also derived from the plant sources. The mutants play important role in the many processes of plant such as developmental, physiological, and metabolic. Also, cofactor and antioxidant roles reported to the vitamin under stress condition in plants (Teresa, 2011). The mutants are essential to biosynthesis pathways of several hormones as a cofactor (Raschke et al., 2011). CSNP $\left(\mathrm{C}_{11} \mathrm{H}_{17} \mathrm{O}_{7} \mathrm{~N}_{2}\right)$ is a polyacetate polysaccharide produced as a natural polymer and from Alkaline $\mathrm{N}$-deacetylation of chitin and is known to be the second most abundant polymer on earth, which is the cell wall of some fungi, insects, and also some algae are produced (Yin et al., 2011). This material can be mentioned from compounds with the properties of opiatetrium that impose plant defense mechanisms against stress and improve plant growth (Gornik et al., 2008; Sheikha and AL-Malki, 2011). Researchers believe that this substance has the ability to increase antioxidant enzyme activities and acts as a neutralizing ROS (Harish et al., 2007). Increasing chlorophyll content in strawberries (El-Miniawy et al., 2013) and rice (Pongprayoon et al., 2013), catalase activity in canola (Yin et al., 2008), soluble protein content in tomato and eggplant (Sultana $e t$ al., 2017) and tomato (Walker-Simmons and Ryan, 1984), soluble sugars and proline content in corn (Guan

et al., 2009) have been reported in different studies with CSNP application. Since salinity stress is limiting factors of seed germination, and seed priming is a favourable method for decrease negative effect of salt stress, so, this research was carried out to improve tolerance to salinity in milk thistle seedling by different concentrations of CSNP and PN.

\section{Materials and Methods}

\section{Priming and salt stress treatments}

Two factorial experiments were carried out to assess the effects of CSNP $(0,0.25 .0 .5$, and $1 \%)$ and PN $(0,0.03,0.06$, and $0.09 \%)$ on germination traits and physiological attributes of seedling of milk thistle under salt stress $(\mathrm{NaCl}$ i.e. $0,50,100$, and $150 \mathrm{mM})$ in a completely randomized design with three replications. Test procedures for two experiments have been adapted from ISTA (International Seed Testing Association) guidelines (ISTA 2009). ISTA recommends germinating milk thistle seeds on between paper or top of paper at constant or alternating temperatures, 25 or $20 / 30{ }^{\circ} \mathrm{C}$, respectively. In both experiments, the seed of milk thistle was immersed in a $5 \%$ sodium hypochlorite solution for $10 \mathrm{~min}$ to ensure surface sterility. Then they were soaked in distilled water (as control), CSNP and PN suspension for about 6 hours at $25 \mathrm{C}$, after being rinsed three times with distilled water. Treated seeds were shade-dried for 12 hour. CSNP and PN were purchased from Sigma-Aldrich, USA. Then the 25 seeds were placed in a Petri dish $(12 \times 1.5 \mathrm{~cm})$ with one piece of sterilized filter paper (Whatman No.1) and $9 \mathrm{~mL}$ of distilled water (for control) or $\mathrm{NaCl}$ solution based on various treatments was added to each Petri dish. Van't Hoff formula (1) was used prepared of salinity 
solution (3.2, 6.4, and $9.6 \mathrm{gr} \mathrm{NaCl}$ per liter for 50, 100 and $150 \mathrm{mM}$, respectively) (Aghighi Shahverdi et al., 2017).

Formula 1) $\Psi=$-MIRT

Whereas $\Psi$ : osmotic potential according to Bar; M: molarity; I: Van 't Hoff factor $=2$ for $\mathrm{NaCl}$; R: constant number $=0.08206$ bar; $T$ : temperature according to Kelvin

Germinated seeds were counted on the second day was done on a daily basis and finally at the end of the testing period (10 days) was calculated GP, GR, MGT, and SVI according to the following formulas (Parmoon et al., 2015; Aghighi Shahverdi et al., 2017).

Germination percentage

Germination rate

$\mathrm{GP}=(\mathrm{N} \times 100) / \mathrm{M}$

Seed vigor index

$\mathrm{GR}=\Sigma \mathrm{Ni} / \mathrm{Ti}$

SVI $=$ GP $\times$ Mean $(S L$ or SDW)

Whereas $\mathrm{N}$ = sum of germinated seeds at the end of the experiment, $\mathrm{M}=$ total planted seeds, $\mathrm{Ti}=$ number of days after germination, $\mathrm{SL}=$ Seedling Length; SDW: seedling dry weight

\section{Threshold and EC50 values}

The threshold values indicate salinity levels $(\mathrm{NaCl})$ where seed begin to experience germinationreducing effects. For this purpose, we used SALT computer program proposed by USDA (United States Department of Agriculture) (Genuchten, 1983) and EC50 ( $\mathrm{NaCl}$ level that 50\% of germination reduction) calculated by Van-Genuchtan and Hoffman (1984) formula (Aghighi Shahverdi et al., 2019).

\section{Photosynthetic pigments}

According to Lichtenthaler (1987) method, $0.25 \mathrm{~g}$ of fresh seedling sample was extracted by using $5 \mathrm{~mL}$ $80 \%$ acetone. The extract was centrifuged at $11000 \mathrm{rpm}$ for $10 \mathrm{~min}$. By using a Spectrophotometer, the extract optical density was measured at wavelengths $470,646.8$, and 663.2 nanometres to estimate photosynthetic pigments.

\section{Proline assay}

Proline was determined according to the method described by Bates et al. (1973). Approximately $0.5 \mathrm{~g}$ of fresh seedling tissue was homogenized in $10 \mathrm{~mL}$ of $3 \%$ aqueous sulfosalicylic acid. Then, this aqueous solution was filtered through Whatman's paper No. 2 and finally, $2 \mathrm{~mL}$ of filtrated solution was mixed with 2 $\mathrm{mL}$ acid-ninhydrin and $2 \mathrm{~mL}$ of glacial acetic acid in a test tube. The mixture was placed in a water bath for 1 $\mathrm{h}$ at $100^{\circ} \mathrm{C}$. The reaction mixture was extracted with $4 \mathrm{~mL}$ toluene, cooled to room temperature, and the absorbance was measured at $520 \mathrm{~nm}$ with a spectrometer" (Aghighi Shahverdi et al., 2017).

\section{Determination of enzyme activities}

To measure the enzyme activity of the total seedling, $0.1 \mathrm{~g}$ of fresh seedling tissue was used. In order to extract protein, $0.2 \mathrm{~g}$ of fresh seedling tissue was pulverized in a mortar using liquid nitrogen and then $1 \mathrm{~mL}$ of buffer Tris- $\mathrm{HCl}(0.05 \mathrm{M}, \mathrm{pH}=7.5)$ was added. Obtained mixture centrifuged for $21 \mathrm{~min}$ at 13,000 rpm, at 4 ${ }^{\circ} \mathrm{C}$ and the supernatant was used for enzyme activity measurements (Sudhakar et al., 2001). Catalase activity (CAT) was determined according to the method described by Kar and Mishra (1976). The $60 \mu \mathrm{L}$ protein extract was added to Tris buffer $(50 \mathrm{mM}, \mathrm{pH}=7) \mathrm{H}_{2} \mathrm{O}_{2} 5 \mathrm{mM}$ in the ice bath, then the absorbance curve was considered at a wavelength of $240 \mathrm{~nm}$ " (Aghighi Shahverdi et al., 2017). Superoxide dismutase activity (SOD) was determined according to the method described by Beauchamp and Fridovich (1971). About $3 \mathrm{~mL}$ of reaction mixture, containing $0.1 \mathrm{~mL}$ of $200 \mathrm{mM}$ methionine, $0.01 \mathrm{~mL}$ of $2.25 \mathrm{mM}$ nitro blue tetrazolium (NBT), $0.1 \mathrm{~mL}$ of $3 \mathrm{mM}$ EDTA, $1.5 \mathrm{~mL}$ of $100 \mathrm{mM}$ potassium phosphate buffer, $1 \mathrm{~mL}$ distilled water and 0.05 $\mathrm{mL}$ of enzyme extraction, were taken in test tubes in duplicate from each enzyme sample. Two tubes without enzyme extract were taken as control. The reaction was started by adding $0.1 \mathrm{~mL}$ riboflavin $(60 \mu \mathrm{M})$ and placing 
the tubes below a light source of two $15 \mathrm{~W}$ fluorescent lamps for $15 \mathrm{~min}$. The reaction was stopped by switching off the light and covering the tubes with black cloth. Absorbance was recorded at $560 \mathrm{~nm}$ " (Aghighi Shahverdi et al., 2017).

\section{Statistical analysis}

Distribution normality of achieved data from both experiments was done according to the KolmogorovSmirnov and Shapiro-Wilk test. Then the studied traits were statistically analyzed by the Statistical Analysis System software (SAS Institute, Cary, NC, USA, and Version 9.2). The differences among means were separated using LSD test (least significant difference) at 0.05 statistical probability level.

\section{Results and Discussion}

\section{Threshold value and germination loss}

Figure 1 indicated threshold and slope values for milk thistle (tolerance based on germination percentage). According to the results achieved from SALT computer models, threshold, EC 50 values (the salinity level that $50 \%$ of germination reduction) and reduction slope were 74.85 and $213.5 \mathrm{mM}$ and 0.25 respectively. In the other words, the increasing $10 \mathrm{mM}$ of salinity concentration caused reduction 0.25 percentage of germination percentage.

\section{Chitosan experiment}

Results indicated that the effect of salinity was significant on all studied traits such as GP, GR, seedling length (SL), seedling dry weight (SDW), seedling length vigor index (SLVI), seedling weight vigor index (SWVI), chlorophyll a (Chl a), chlorophyll b (Chl b), total chlorophyll (total Chl), CAT, SOD, and proline content. In addition, seed priming with CSNP significantly affected germination parameters and physiological attributes, however, the activity of CAT and SOD enzymes were not affected (Table 1). The interaction between salinity stress and CSNP priming was significant on MTG, GR, SDW, Chl a, Chl b, total Chl, CAT, and proline. A significant reduction in GP (49.12\%), SL (50.07\%) SLVI (34.76\%), and SWVI (67.39\%) while, a significant increase in SOD activity $(54.63 \%)$ were found at $150 \mathrm{mM} \mathrm{NaCl}$ in compared to the control treatment (Table 1). On the other hand, results indicated that CSNP priming, especially at $0.25 \%$ concentration, was caused to improve germination and physiological traits. A reduction in germination parameters such as GP and SWVI was observed in 1\% concentration of CSNP (Table 1). The highest value of MGT was achieved 50 and $100 \mathrm{mM} \mathrm{NaCl}$ under $1 \%$ concentration of CSNP (4.52 and 4.51 day, respectively). The lowest value of the trait (3 days) was observed in $100 \mathrm{mM} \mathrm{NaCl}$ with $0.25 \%$ concentration of CSNP (Figure 2-A). The largest GR (5.7 seed/day) was resulted by $100 \mathrm{mM} \mathrm{NaCl}$ and $0.25 \% \mathrm{CSNP}$ and the least (2.86 seed/day) by $150 \mathrm{mM} \mathrm{NaCl}$ and without CSNP. Also, 0 and $50 \mathrm{mM} \mathrm{NaCl}$ under non-application CSNP and $0.25 \%$ CSNP had the highest value of the trait (Figure 2-B). The highest seedling dry weight (31.8 g) was achieved $50 \mathrm{mM} \mathrm{NaCl}$ and 1\% CSNP and the lowest (25.13 g) in $100 \mathrm{mM} \mathrm{NaCl}$ and 0.5\% CSNP (Figure 2C).

Results indicated that the salinity stress significantly decreased photosynthetic pigments, however, the largest values of $\mathrm{Chl}$ a, $\mathrm{Chl} \mathrm{b}$, and total $\mathrm{Chl}(17.95,8.97$, and $26.94 \mu \mathrm{g} / \mathrm{g} \mathrm{FW})$ was related to without $\mathrm{NaCl}$ and $1 \%$ CSNP and the least value of traits $(6.1,1.67$, and $7.77 \mu \mathrm{g} / \mathrm{g} \mathrm{FW})$ to non-application of CSNP under 150 $\mathrm{mM} \mathrm{NaCl}$ (Figure 3-A, B, C). Salinity stress significantly increased CAT activity while CSNP application decreased CAT activity (Figure 3-D). The highest CAT activity $(2.42 \mathrm{U} / \mathrm{min} \mathrm{mg}$ protein) related to nonapplication of CSNP under $150 \mathrm{mM} \mathrm{NaCl}$ and the lowest activity of the enzyme to 0 and $50 \mathrm{mM} \mathrm{NaCl}$ concentrations under all treatments of CSNP (Figure 3-D). Free proline content increased by salinity stress under all CSNP treatments. Free proline content was in the range of $347.1(150 \mathrm{mM} \mathrm{NaCl}$ and $1 \% \mathrm{CSNP})$ and $89.9 \mu \mathrm{mol} / \mathrm{g} \mathrm{FW}$ (control treatment) (Figure 3-E). 


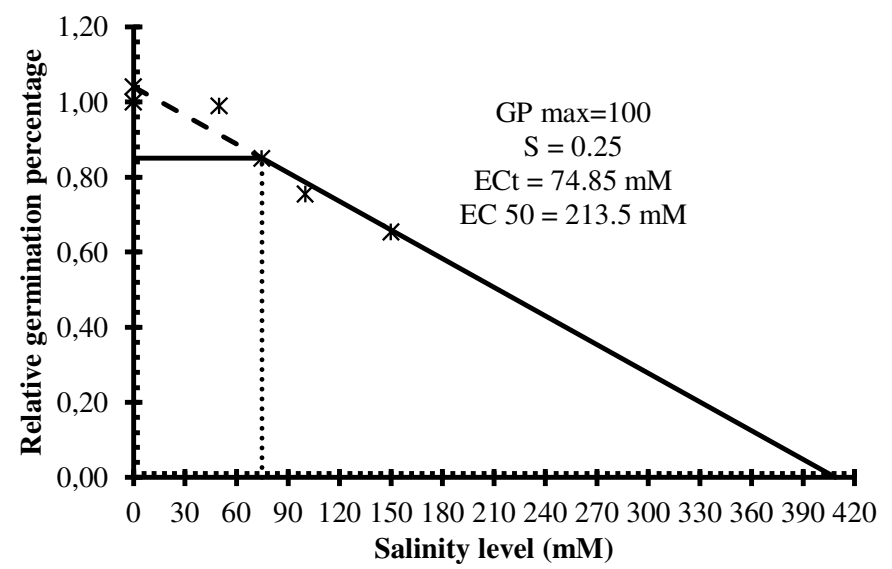

Figure 1. Threshold, slope and $\mathrm{EC}_{50}$ values in milk thistle seed during germination stage
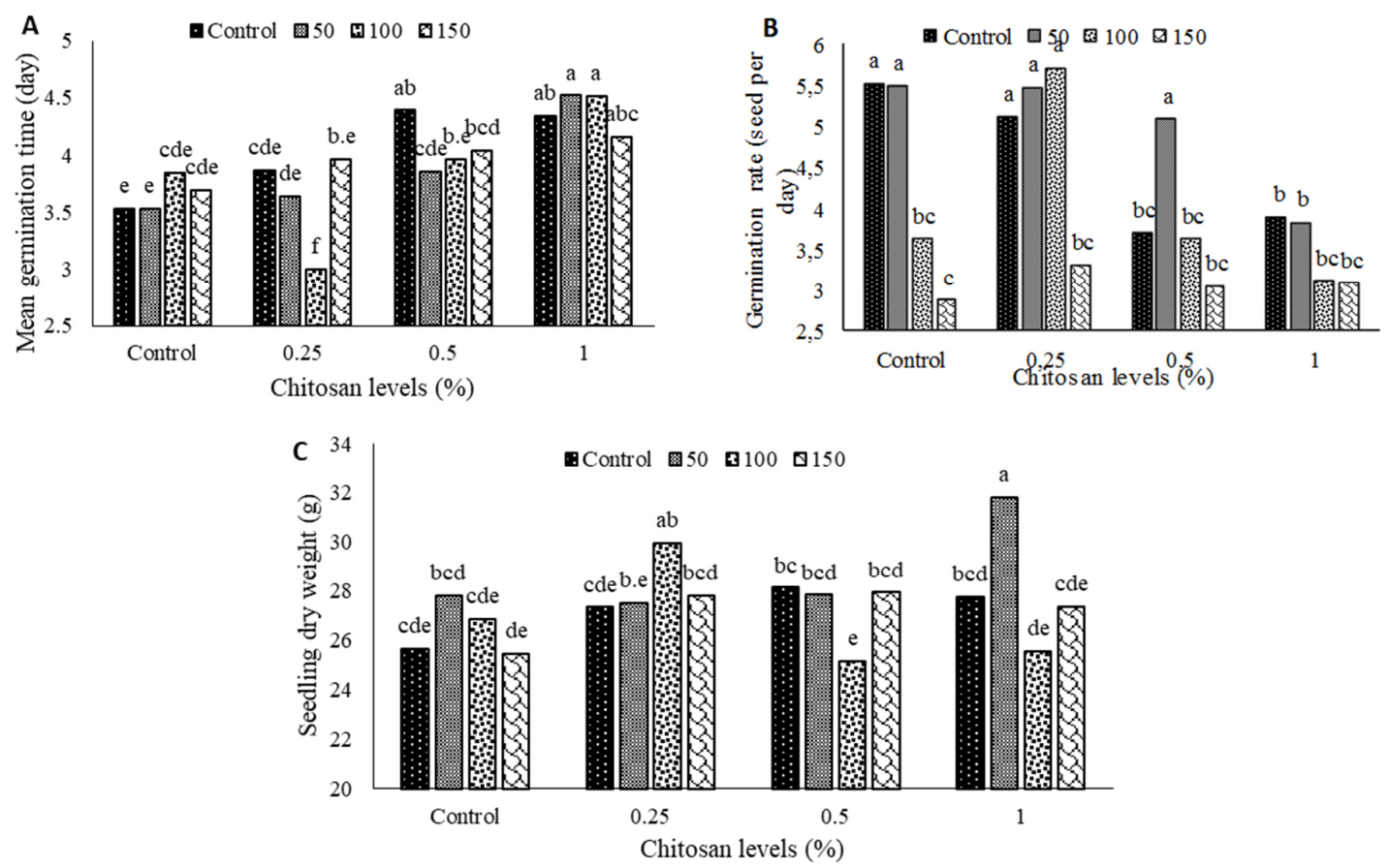

Figure 2. Effects of salinity stress (0.50. 100 , and $150 \mathrm{mM} \mathrm{NaCl})$ and CSNP concentrations $(0,0.25,0.5$, and $1 \%$ ) on mean germination time (A), germination rate (B), and seedling dry weight (C) of milk thistle seeds (means followed by the same letter are not significantly different according to LSD test at $5 \%$ level) 

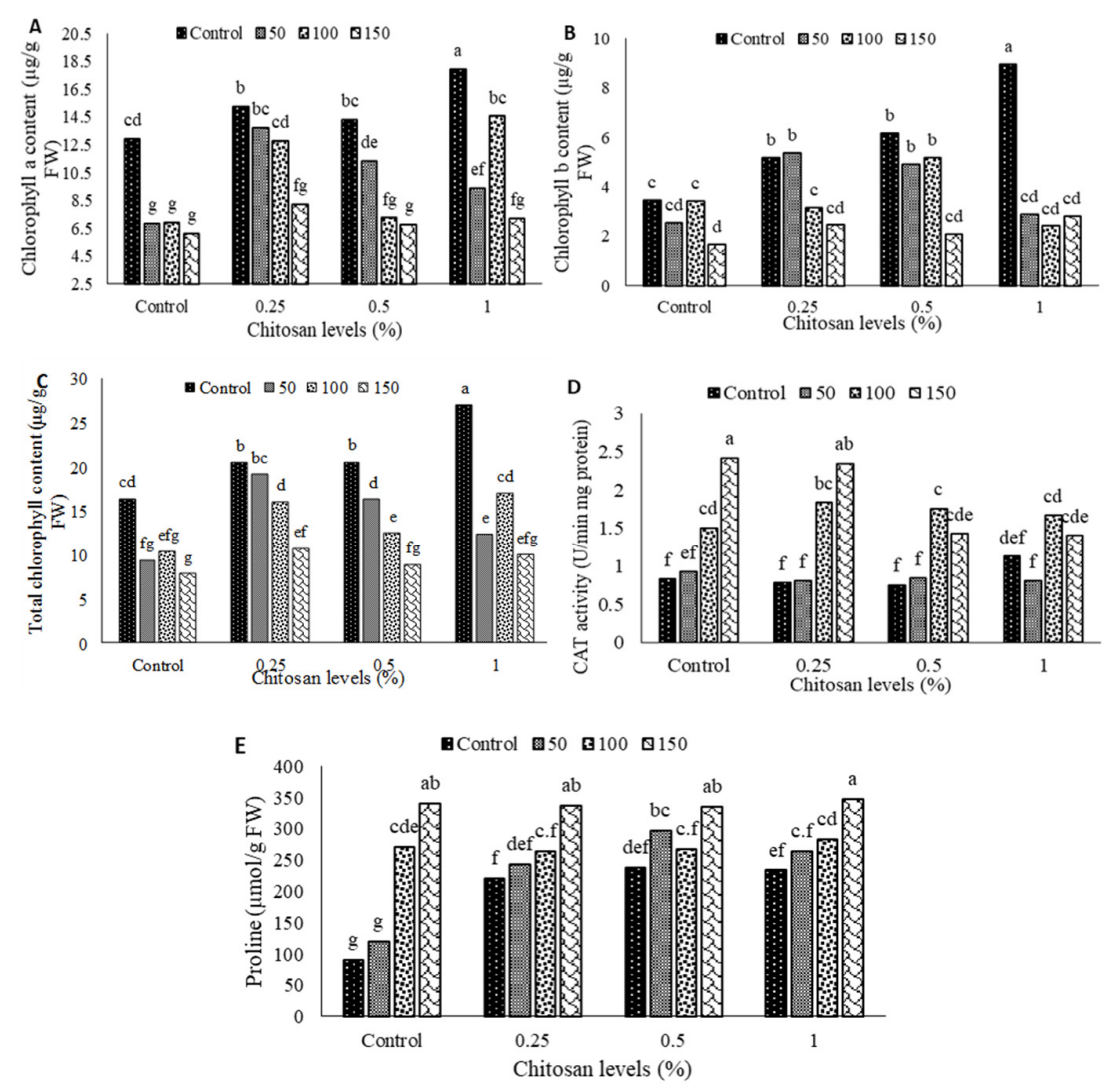

Figure 3. Effects of salinity stress $(0.50 .100$, and $150 \mathrm{mM} \mathrm{NaCl})$ and CSNP concentrations $(0,0.25,0.5$, and $1 \%$ ) on chlorophyll a (A), chlorophyll b (B), total chlorophyll (C), CAT activity (D), and proline content $(\mathrm{E})$ of milk thistle seeds (means followed by the same letter are not significantly different according to LSD test at $5 \%$ level)

Table 1. Effect of different levels of salinity stress (control, 50, 100, and $150 \mathrm{mM}$ ) and Chitosan (control, $0.25,0.5$, and $1 \%$ ) on germination indices and physiological traits of milk thistle seedling

\begin{tabular}{|c|c|c|c|c|c|c|c|c|c|c|c|c|c|}
\hline \multirow[t]{2}{*}{ Treatments } & \multirow[t]{2}{*}{$\begin{array}{l}\text { GP } \\
(\%)\end{array}$} & \multirow[t]{2}{*}{$\begin{array}{l}\text { MGT } \\
\text { (day) }\end{array}$} & \multirow[t]{2}{*}{$\begin{array}{c}\mathrm{GR} \\
\text { (seed/day) }\end{array}$} & \multirow[t]{2}{*}{$\begin{array}{l}\mathrm{SL} \\
(\mathrm{cm})\end{array}$} & \multirow[t]{2}{*}{$\begin{array}{l}\text { SDW } \\
(\mathrm{g})\end{array}$} & \multirow[t]{2}{*}{ SLVI } & \multirow[t]{2}{*}{ SWVI } & $\begin{array}{c}\mathrm{Chl} \\
\mathrm{a}\end{array}$ & $\begin{array}{c}\text { Chl } \\
\mathrm{b}\end{array}$ & $\begin{array}{c}\text { Total } \\
\text { Chl }\end{array}$ & \multirow{2}{*}{$\begin{array}{c}\text { CAT } \\
(\mathrm{U} / \mathrm{mg} \\
\text { protein.min })\end{array}$} & \multirow{2}{*}{$\begin{array}{c}\text { SOD } \\
(\mathrm{U} / \mathrm{mg} \\
\text { protein) }\end{array}$} & \multirow[t]{2}{*}{$\begin{array}{c}\text { Proline } \\
(\mu \mathrm{mol} / \mathrm{g} \\
\mathrm{FW})\end{array}$} \\
\hline & & & & & & & & \multicolumn{3}{|c|}{$(\mu \mathrm{g} / \mathrm{g} \mathrm{FW})$} & & & \\
\hline \multicolumn{14}{|l|}{$\begin{array}{c}\begin{array}{c}\text { Salinity } \\
\text { levels } \\
(\mathrm{mM} \mathrm{NaCl})\end{array} \\
\end{array}$} \\
\hline Control & $68.0 \mathrm{a}$ & $4.0 \mathrm{a}$ & $4.5 \mathrm{a}$ & $13.3 \mathrm{a}$ & $27.2 \mathrm{~b}$ & $900.9 \mathrm{a}$ & $1844.1 \mathrm{a}$ & $15.1 \mathrm{a}$ & $5.9 \mathrm{a}$ & $21.0 \mathrm{a}$ & $0.85 \mathrm{~b}$ & $1.9 \mathrm{c}$ & $195.5 \mathrm{~d}$ \\
\hline 50 & $69.6 \mathrm{a}$ & $3.89 \mathrm{a}$ & $4.9 \mathrm{a}$ & $13.1 \mathrm{a}$ & $28.7 \mathrm{a}$ & $920.7 \mathrm{a}$ & $2004.2 \mathrm{a}$ & $10.3 \mathrm{~b}$ & $3.9 \mathrm{~b}$ & $14.2 \mathrm{~b}$ & $0.87 \mathrm{~b}$ & $2.0 \mathrm{c}$ & $231.2 \mathrm{c}$ \\
\hline 100 & $54.6 \mathrm{~b}$ & $3.83 \mathrm{a}$ & $4.0 \mathrm{~b}$ & $8.79 \mathrm{~b}$ & $26.8 \mathrm{~b}$ & $491.7 b$ & $1473.6 \mathrm{~b}$ & $10.3 \mathrm{~b}$ & $3.5 \mathrm{~b}$ & $13.9 \mathrm{~b}$ & $1.7 \mathrm{a}$ & $2.6 \mathrm{~b}$ & $271.5 \mathrm{~b}$ \\
\hline 150 & $45.6 \mathrm{c}$ & $3.96 \mathrm{a}$ & $3.0 \mathrm{c}$ & $6.66 c$ & $27.1 \mathrm{~b}$ & $313.2 \mathrm{c}$ & $1242.9 \mathrm{c}$ & $7.0 \mathrm{c}$ & $2.2 \mathrm{c}$ & $9.3 c$ & $1.9 \mathrm{a}$ & $3.0 \mathrm{a}$ & $340.0 \mathrm{a}$ \\
\hline $\begin{array}{c}\text { LSD } \\
(\mathrm{P}=0.05)\end{array}$ & 5.23 & 0.23 & 0.45 & 2.03 & 1.26 & 162.6 & 166.6 & 1.0 & 0.72 & 1.4 & 0.28 & 0.22 & 24.3 \\
\hline \multicolumn{14}{|l|}{$\begin{array}{l}\text { Chitosan } \\
\text { levels (\%) }\end{array}$} \\
\hline Control & $57.3 \mathrm{~b}$ & $3.6 \mathrm{c}$ & $4.3 \mathrm{~b}$ & $5.79 \mathrm{~b}$ & $26.4 \mathrm{~b}$ & $350.9 \mathrm{~b}$ & $1519.3 \mathrm{~b}$ & $8.1 \mathrm{c}$ & $2.7 \mathrm{~b}$ & $10.9 \mathrm{c}$ & $1.4 \mathrm{a}$ & $2.37 \mathrm{a}$ & $205.3 \mathrm{~b}$ \\
\hline 0.25 & $64.0 \mathrm{a}$ & $3.6 \mathrm{c}$ & $4.8 \mathrm{a}$ & $11.59 \mathrm{a}$ & $28.1 \mathrm{a}$ & $776.6 a$ & $1798.7 \mathrm{a}$ & $12.4 \mathrm{a}$ & $4.0 \mathrm{a}$ & $16.5 a$ & $1.4 \mathrm{a}$ & $2.52 \mathrm{a}$ & $2.66 .7 \mathrm{a}$ \\
\hline 0.5 & $58.3 \mathrm{~b}$ & $4.0 \mathrm{~b}$ & $3.8 \mathrm{c}$ & $11.74 \mathrm{a}$ & $27.2 \mathrm{ab}$ & $713.6 a$ & $1592.5 \mathrm{~b}$ & $9.9 \mathrm{~b}$ & $4.5 \mathrm{~b}$ & $14.5 \mathrm{~b}$ & $1.2 \mathrm{a}$ & $2.26 \mathrm{a}$ & $284.2 \mathrm{a}$ \\
\hline 1 & $58.3 \mathrm{~b}$ & $4.3 \mathrm{a}$ & $3.4 \mathrm{c}$ & $12.80 \mathrm{a}$ & $28.1 \mathrm{a}$ & $785.6 \mathrm{a}$ & $1654.1 \mathrm{ab}$ & $12.2 \mathrm{a}$ & $4.2 \mathrm{~b}$ & $16.5 \mathrm{a}$ & $1.2 \mathrm{a}$ & $2.48 \mathrm{a}$ & $282.0 \mathrm{a}$ \\
\hline $\begin{array}{c}\text { LSD } \\
(\mathrm{P}=0.05)\end{array}$ & 5.23 & 0.23 & 0.45 & 2.03 & 1.26 & 162.6 & 166.6 & 1.09 & 0.72 & 1.42 & 0.28 & 0.52 & 24.3 \\
\hline $\begin{array}{l}\text { Salinity } \times \\
\text { Chitosan }\end{array}$ & NS & ${ }^{* *}$ & ${ }^{* *}$ & Ns & ** & NS & NS & ${ }^{* *}$ & $* *$ & ** & ${ }^{* *}$ & NS & ** \\
\hline $\begin{array}{l}\mathrm{M} \\
\mathrm{N}\end{array}$ & $\begin{array}{l}\text { ollowe } \\
\text {-signif } \\
\text { ninatic } \\
\text { f vigor }\end{array}$ & $\begin{array}{l}\text { the sa } \\
t^{* *} \text { : si } \\
\text { ercent }\end{array}$ & $\begin{array}{l}\text { tter in ea } \\
\text { ant at } \alpha= \\
\text { MGT: me } \\
\text { seedling }\end{array}$ & $\begin{array}{l}\text { imn ar } \\
1 . \\
\text { minat } \\
\text { of vigo }\end{array}$ & $\begin{array}{l}\mathrm{ne} ; \mathrm{G} \\
\mathrm{x} ; \mathrm{Cl}\end{array}$ & $\begin{array}{l}\text { rmina } \\
\text { hloro }\end{array}$ & $\begin{array}{l}\text { ate; SL } \\
\text {; Chl b }\end{array}$ & $\begin{array}{l}\text { lling } 1 \\
\text { oroph }\end{array}$ & $5 \%$ & $\begin{array}{l}\text { see } \\
\text { Chl: }\end{array}$ & $\begin{array}{l}\text { dry weight } \\
\text { chlorophyll }\end{array}$ & $\begin{array}{l}\text { I: seedling } \\
\text { I: catalase }\end{array}$ & \\
\hline
\end{tabular}


Pyridoxine experiment

In the PN experiment, the effect of salinity was significant on GP, MTG, GR, SDW, SLVI, SWVI, Chl a, Chl b, total Chl, CAT, SOD, and proline content. The effect of PN seed priming was significant on germination indices such as SL and SLVI and seedling physiological traits such as Chl a, Chl b, total Chl, CAT, SOD, and proline content. Interaction salinity and PN had a significant effect on MTG, SL, SLVI, CAT, and proline (Table 2). Like the CSNP experiment, $150 \mathrm{mM} \mathrm{NaCl}$ concentration was caused decreases GP (36.36\%), GR (57.28\%), SWVI (35.79\%), Chl a (20.70\%), Chl b (53.39\%), and total Chl (32.58\%) compared to the control treatment. On the other hand, PN application increased SWVI, Chl a, Chl b, and total Chl (Table 2).

In the interaction salinity $\times \mathrm{PN}$, the highest MGT was achieved 100 and $150 \mathrm{mM} \mathrm{NaCl}$ under all PN levels. The lowest value (3.27 day) of traits related to control treatment (Figure 3-A). Results indicated that the application of PN (0.06 and $0.09 \%$ concentrations) was caused increased SL under high level of salinity. The highest SL was related to $0.09 \% \mathrm{PN}$ priming treatment under 100 and $150 \mathrm{mM} \mathrm{NaCl}(15.69$ and $16.1 \mathrm{~cm}$, respectively) and the lowest to 0 and $0.03 \% \mathrm{PN}$ under 100 and $150 \mathrm{mM} \mathrm{NaCl}$ (Figure 4-B). Seedling length vigor index was in the range of 988.8 (non-stressed and 0.03\% PN) and 185.7 (non-application PN and 150 $\mathrm{mM} \mathrm{NaCl}$ ) (Figure 4-C).

The results showed that, like the CSNP experiment, an increase in CAT activity and proline content increased with salt stress. However, the highest CAT activity ( 0.93 and $0.94 \mathrm{U} / \mathrm{min} \mathrm{mg}$ protein) was observed control and $0.09 \%$ concentrations of PN under $150 \mathrm{mM}$ salinity treatment. The lowest value of the trait was related to control treatment (non-stressed and non-application) (Figure 5-A). PN application was caused a decrease in free proline content compared to the non-application treatment. The largest proline content (393.3 $\mu \mathrm{mol} / \mathrm{g} \mathrm{FW}$ ) was related to non-application of $\mathrm{PN}$ under $150 \mathrm{mM} \mathrm{NaCl}$ and the lowest to control treatment (non-stressed and non-application) (Figure 5-B).

Table 2. Effect of different levels of salinity stress (control, 50, 100, and $150 \mathrm{mM}$ ) and Pyridoxine (control, $0.03,0.06$, and $0.09 \%$ ) on germination indices and physiological traits of milk thistle seedling

\begin{tabular}{|c|c|c|c|c|c|c|c|c|c|c|c|c|c|}
\hline \multirow[t]{2}{*}{ Treatments } & \multirow{2}{*}{$\begin{array}{l}\text { GP } \\
(\%)\end{array}$} & \multirow{2}{*}{$\begin{array}{l}\text { MGT } \\
\text { (day) }\end{array}$} & \multirow{2}{*}{$\begin{array}{c}\text { GR } \\
\text { (seed/day) }\end{array}$} & \multirow{2}{*}{$\begin{array}{l}\mathrm{SL} \\
(\mathrm{cm})\end{array}$} & \multirow{2}{*}{$\begin{array}{l}\text { SDW } \\
(\mathrm{g})\end{array}$} & \multirow[t]{2}{*}{ SLVI } & \multirow[t]{2}{*}{ SWVI } & $\mathrm{Chl} \mathrm{a}$ & Chl b & $\begin{array}{l}\text { Total } \\
\text { Chl }\end{array}$ & \multirow{2}{*}{$\begin{array}{c}\text { CAT } \\
(\mathrm{U} / \mathrm{mg} \\
\text { protein.min) } \\
\end{array}$} & \multirow{2}{*}{$\begin{array}{c}\text { SOD } \\
\text { (U/mg } \\
\text { protein) }\end{array}$} & \multirow{2}{*}{$\begin{array}{c}\text { Proline } \\
(\mu \mathrm{mol} / \mathrm{g} \\
\mathrm{FW})\end{array}$} \\
\hline & & & & & & & & \multicolumn{3}{|c|}{$(\mu \mathrm{g} / \mathrm{g} \mathrm{FW})$} & & & \\
\hline $\begin{array}{c}\text { Salinity } \\
\text { levels }(\mathrm{mM} \\
\mathrm{NaCl})\end{array}$ & & & & & & & & & & & & & \\
\hline Control & $66.0 \mathrm{a}$ & $3.6 \mathrm{~b}$ & $5.15 \mathrm{a}$ & $9.6 \mathrm{a}$ & $20.6 \mathrm{a}$ & $639.1 \mathrm{a}$ & $1362.8 \mathrm{a}$ & $19.8 \mathrm{a}$ & $11.5 \mathrm{a}$ & $31.3 \mathrm{a}$ & $0.29 \mathrm{~d}$ & $0.97 \mathrm{~b}$ & $78.0 \mathrm{c}$ \\
\hline 50 & $63.0 \mathrm{a}$ & $3.7 \mathrm{~b}$ & $4.65 \mathrm{a}$ & $10.4 \mathrm{a}$ & $20.7 \mathrm{a}$ & $649.3 a$ & $1310.5 \mathrm{a}$ & $20.2 \mathrm{a}$ & $10.9 \mathrm{a}$ & $31.1 \mathrm{a}$ & $0.35 \mathrm{c}$ & $0.98 \mathrm{~b}$ & $116.9 \mathrm{~b}$ \\
\hline 100 & $46.6 \mathrm{~b}$ & $5.1 \mathrm{a}$ & $2.37 \mathrm{~b}$ & $9.5 \mathrm{a}$ & $20.8 \mathrm{a}$ & $417.2 \mathrm{~b}$ & $971.7 \mathrm{~b}$ & $18.94 \mathrm{a}$ & $8.26 \mathrm{~b}$ & $27.2 \mathrm{~b}$ & $0.65 \mathrm{~b}$ & $0.96 \mathrm{~b}$ & $132.3 \mathrm{~b}$ \\
\hline 150 & $42.0 \mathrm{~b}$ & $5.1 \mathrm{a}$ & $2.20 \mathrm{~b}$ & $8.1 \mathrm{a}$ & $20.7 \mathrm{a}$ & $347.4 \mathrm{~b}$ & $875.0 \mathrm{~b}$ & $15.7 \mathrm{~b}$ & $5.36 c$ & $21.1 \mathrm{c}$ & $0.89 \mathrm{a}$ & $1.67 \mathrm{a}$ & $332.7 \mathrm{a}$ \\
\hline $\begin{array}{c}\text { LSD } \\
(\mathrm{P}=0.05)\end{array}$ & 7.00 & 0.23 & 0.53 & 2.44 & 0.44 & 164.0 & 149.4 & 1.93 & 1.45 & 2.47 & 0.05 & 0.14 & 22.9 \\
\hline $\begin{array}{l}\text { Pyridoxine } \\
\text { levels (\%) }\end{array}$ & & & & & & & & & & & & & \\
\hline Control & $55.60 \mathrm{a}$ & $4.3 \mathrm{a}$ & $3.52 \mathrm{a}$ & $6.7 c$ & $20.4 \mathrm{~b}$ & $357.4 \mathrm{~b}$ & $1037.2 \mathrm{~b}$ & $16.2 \mathrm{~b}$ & $8.42 b$ & $24.7 \mathrm{~b}$ & $0.57 \mathrm{~b}$ & $1.36 \mathrm{a}$ & $175.2 \mathrm{a}$ \\
\hline 0.03 & $57.33 a$ & $4.4 \mathrm{a}$ & $3.74 \mathrm{a}$ & $9.3 \mathrm{~b}$ & $20.9 \mathrm{a}$ & $581.2 \mathrm{a}$ & $1201.9 \mathrm{a}$ & $20.0 \mathrm{a}$ & $10.11 \mathrm{a}$ & $30.1 \mathrm{a}$ & $0.50 \mathrm{c}$ & $1.06 \mathrm{~b}$ & $163.9 \mathrm{ab}$ \\
\hline 0.06 & $57.33 a$ & $4.4 \mathrm{a}$ & $3.68 \mathrm{a}$ & $9.3 \mathrm{~b}$ & $20.6 \mathrm{ab}$ & $537.0 \mathrm{a}$ & $1187.6 \mathrm{a}$ & $19.3 \mathrm{a}$ & $9.95 \mathrm{a}$ & $29.2 \mathrm{a}$ & $0.65 \mathrm{a}$ & $1.07 \mathrm{~b}$ & $144.8 \mathrm{~b}$ \\
\hline 0.09 & $52.33 \mathrm{a}$ & $4.4 \mathrm{a}$ & $3.43 \mathrm{a}$ & $12.2 \mathrm{a}$ & $20.9 \mathrm{a}$ & $577.5 \mathrm{a}$ & $1093.2 \mathrm{ab}$ & $19.0 \mathrm{a}$ & $7.63 \mathrm{~b}$ & $26.69 b$ & $0.46 c$ & $1.10 \mathrm{~b}$ & $176.1 \mathrm{a}$ \\
\hline $\begin{array}{c}\text { LSD } \\
(\mathrm{P}=0.05)\end{array}$ & 7.00 & 0.23 & 0.53 & 2.44 & 0.44 & 164.0 & 149.4 & 1.93 & 1.45 & 2.47 & 0.05 & 0.14 & 22.9 \\
\hline $\begin{array}{c}\text { Salinity } \times \\
\text { Pyridoxine }\end{array}$ & NS & ** & NS & ** & ** & ** & NS & NS & NS & NS & ** & NS & ** \\
\hline
\end{tabular}

Means followed by the same letter in each column are not significantly different according to LSD test at $5 \%$ level NS: non-significant; ${ }^{* *}$ : significant at $\alpha=\alpha=0.01$.

GP: germination percentage; MGT: mean germination time; GR: germination rate; SL: seedling length; SDW: seedling dry weight; SLVI: seedling length of vigor index; SWVI: seedling weight of vigor index; Chl a: chlorophyll a; Chl b: chlorophyll b; Total Chl: total chlorophyll; CAT: catalase activity; SOD: superoxide dismutase activity. 

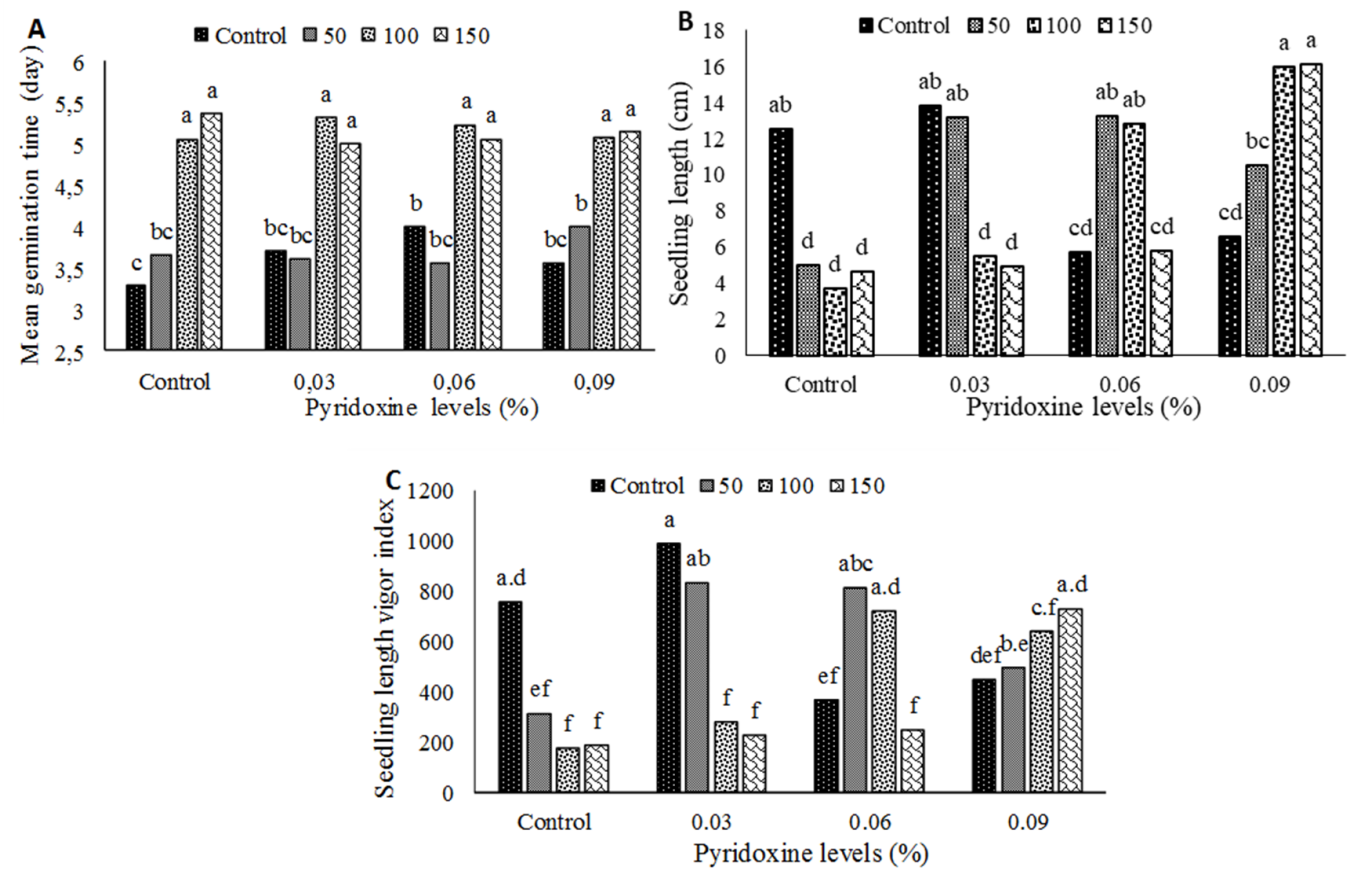

Figure 4. Effects of salinity stress (0. 50. 100, and $150 \mathrm{mM} \mathrm{NaCl})$ and $\mathrm{PN}$ concentrations $(0,0.03,0.06$, and $0.09 \%$ ) on mean germination time (A), seedling length (B), and seedling length vigor index (C) of milk thistle seeds (means followed by the same letter are not significantly different according to LSD test at 5\% level)
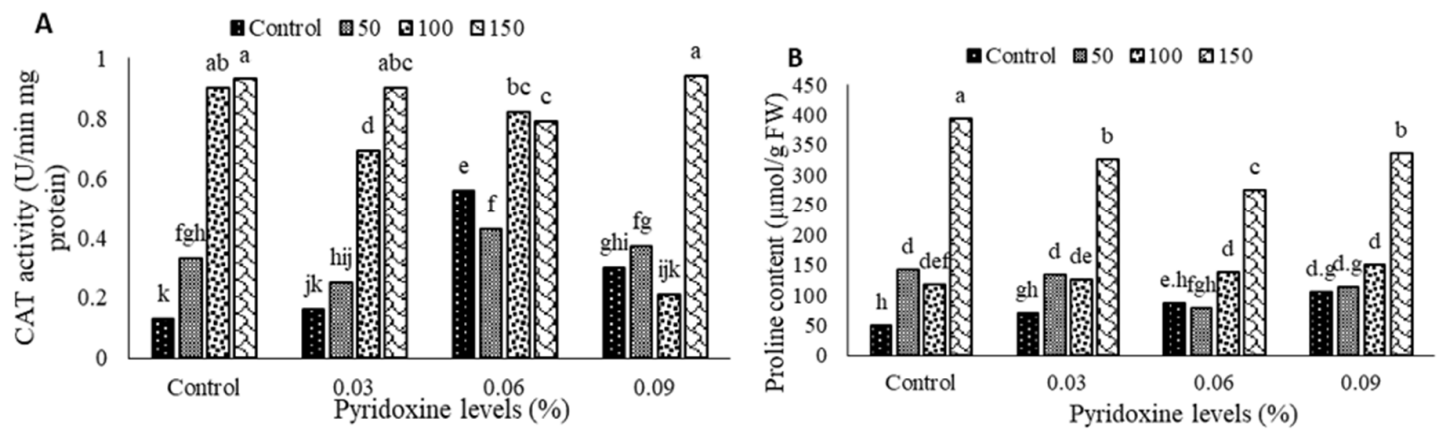

Figure 5. Effects of salinity stress $(0.50 .100$, and $150 \mathrm{mM} \mathrm{NaCl})$ and Pyridoxine concentrations $(0,0.03$, 0.06 , and $0.09 \%$ ) on CAT activity (A) and proline content (B) of milk thistle seeds (means followed by the same letter are not significantly different according to LSD test at $5 \%$ level) 

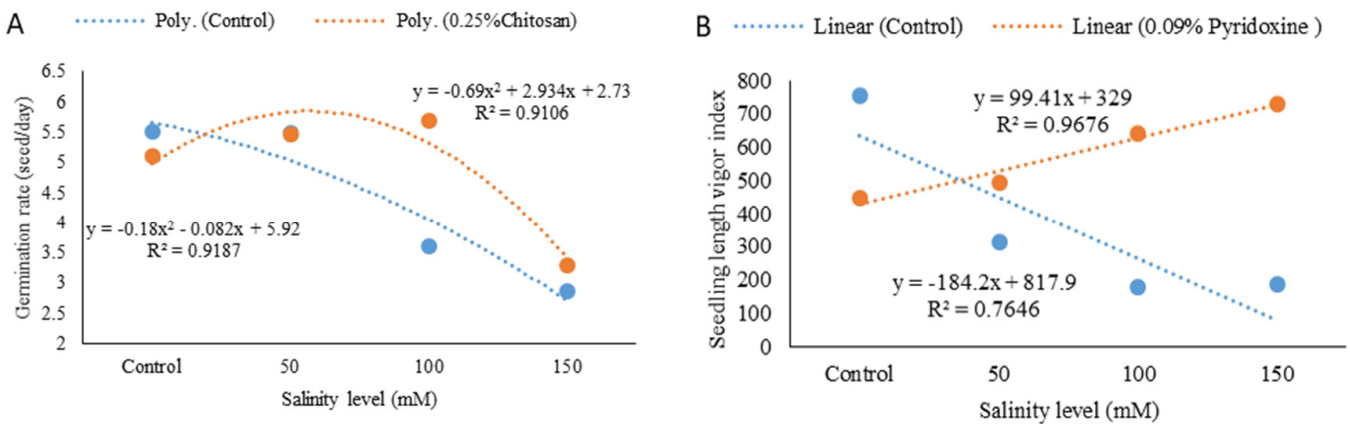

Figure 6. Germination rate (A) response of milk thistle to application of $0.25 \%$ chitosan (A) and seedling length vigour index response of milk thistle to application of $0.09 \%$ pyridoxine under different salinity levels.

\section{Discussion}

Evaluation the role of CSNP and PN seed priming on improve tolerance to the salinity stress was one of the objectives in the present investigations. In the both of experiments (CSNP and PN), salinity stress significantly decreased germination indices such as GP, GR, SL, SLVI, and SWVI and seedling physiological traits such as $\mathrm{Chl}$ a, Chl b, and total Chl, while the increased activity of CAT and SOD enzymes and free proline content. Enhance levels of salinity decrease the water potential and resulted water less available to the seed. Osmotic and/or ionic effects of salinity stress were caused decreasing GP and GR in compared to the nonstress condition (Ghavami and Ramin, 2007). The decrease of water content under salt condition due to declines turgor pressure in the plant, and therefore prevents cell division, cell enlargement, and plant growth (Farooq et al., 2009). Based on reports of Ghavami and Ramin (2007), it may be determined that the plant at the seed germination phase may be categorized as a facultative halophyte, which confirms the results of this study.

Under salinity stress conditions, limited stomatal conductance, diminished activities of carbon fixation enzymes, reduced quantities of photosynthetic pigments, and destruction of photosynthetic apparatus are among the key factors limiting the process of photosynthesis ( $\mathrm{Qu}$ et al., 2012; Imran et al., 2018). In line with our results, it has been detected a reduction in photosynthetic pigments in different plants under $\mathrm{NaCl}$ stress (Cha-Um and Kirdmanee, 2009; Aghighi Shahverdi et al., 2017). Augmented generation of reactive oxygen species (ROS) causes damages to cellular components under salt conditions which could result in progressive oxidative damages (Sharma et al., 2012; Imran et al., 2018). It reported that the higher ROS increased damages to chlorophyll pigments (Verma and Mishra, 2005).

Enzymatic and non-enzymatic antioxidants response are defensive mechanisms to overcome oxidative stress (Lipiec et al., 2013; Demidchik, 2015). Proline, non-enzymatic antioxidants response, is known to act as an osmolyte /osmoprotectant agent under drought or salinity stress (Lehmann et al., 2010). The osmolyte has an important role in the scavenging free radicals, osmotic pressure adjustment, stabilizing sub-cellular structures and storing carbon and nitrogen (Gorzi et al., 2018). The results of current study concluded that a significant increase in the free proline content and activity of CAT and SOD enzymes under salt stress especially in $150 \mathrm{mM} \mathrm{NaCl} \mathrm{level.}$

Seed priming is a common technique involving the direct application of plant growth regulators to seeds that are known to improve stress tolerance and increase overall seedling growth (Keshavarz and Ghol Moghadam, 2017). In the current study, the seed priming with CSNP and PN significantly enhanced some 
230

germination indices and seedling physiological traits. In this regard, Ferreira et al. (2016) reported that seed priming with PN solution enhance GR and promotes more uniform germination of durum wheat in stress conditions which confirm the findings of this study. Also, it suggests that seed priming with CSNP may improve the germination rate of maize seed and benefit for seedling growth under stress conditions (Guan $e t$ al., 2009).

Results demonstrated that seed priming with CSNP and PN significantly increases germination parameters and seedling physiological traits. The most pronounced effects of CSNP and PN were recorded in 0.25 and $0.09 \%$ concentrations, respectively. Seed priming by $0.25 \%$ CSNP under $100 \mathrm{mM} \mathrm{NaCl}$ increased GR up 36.6\% and also, priming by $0.09 \% \mathrm{PN}$ under $150 \mathrm{mM} \mathrm{NaCl}$ increased SLVI up 74.55\% (Figure 6). Furthermore, seed priming with CSNP and PN was caused by moderating the negative effects of salinity stress. It seems that increasing photosynthetic pigments, modifying the activity of antioxidant enzymes, and increasing the synthesis of secondary metabolites, such as proline amino acid, has the effect of modulating the negative effects of salinity stress, which caused the tolerance of this plant to salt stress.

Some researchers reported that the B group vitamins are known to promote seedling growth and beneficial effect in various plant species (Keshavarz and Ghol Moghadam, 2017). Burguieres et al. (2007) reported that the application of vitamin B1 by increasing free proline content due to moderate the negative effect of osmotic stress. This proposes that it contributed to osmotic adjustment and cell water status adjustment, so it can play an important role in alleviating salinity stress. Moreover, this vitamin may act as a growth inducer, which can play a role in mitigating the inhibitory effects of $\mathrm{NaCl}$ stress on processes related to seedling growth through enhancing stimulating cell division or cell enlargement (Keshavarz and Ghol Moghadam, 2017). These results can be related to earlier studies that reported that vitamins application could promote and counteract stress-induced factors on growth inhibition in a range of crop species (Dolatabadian et al., 2008). Seed priming by vitamin B12 resulted in improving plant growth and moderating effect under stress and non-stress conditions and caused a significant enhance in growth parameters in salt-stressed plants (Keshavarz and Ghol Moghadam, 2017).

Seed priming by CSNP under stress condition was caused highly improved germination parameters and reduced germination time to promote early seed germination and harmonized growth in rice (Suchada et al., 2007) and maize (Guan et al., 2009). Sadeghi et al. (2011) reported that the reserve mobilization of food material, activation, and re-synthesis of some enzymes, DNA and RNA synthesis started during osmotic priming resulted improvement in germination and vigor of soybean plant. There is a possibility that similar germination responsive genes may be activated because of CSNP priming under osmotic stress. The results of current experiment are in line with these previous reports as GP, GR, SVI, and germination energy were improved while MGT was reduced by CSNP priming (Hameed et al., 2014). Anusuya and Banu (2016) stated that Chitosan significantly promoted growth and biochemical variation capabilities of chickpea. Generally, the effect of CSNP on plants is complex and many factors can affect seed germination, plant growth, and physiological parameters. In the current study, the positive effect of CSNP was observed for milk thistle seedling.

\section{Conclusions}

$\mathrm{NaCl}$ stress had a negative effect on seed germination and seedling growth of milk thistle. Salt tolerance threshold results showed that this seed had a favorable tolerance to salinity stress at the germination stage. Due to the decrease in the GP and GR as well as SVI occur in higher than $100 \mathrm{mM}$ salinity levels. Also, seed priming with CSNP and PN has improved germination indices and seedling physiological parameters such as chlorophyll, proline, and the activity of the antioxidant enzyme. The most pronounced effects of CSNP and PN were recorded in 0.25 and $0.09 \%$ concentrations, respectively. The finding of this study leads to the 
conclusion that seed priming with CSNP and PN by improving physiological mechanisms such as synthesis of photosynthetic pigment, antioxidant enzymes activity, and proline amino acid moderated the negative effects of salinity stress and increased GP, GR, and seedling growth. The co-application of CSNP and PN is recommended for further research at higher different sources of salt stress.

\section{Conflict of Interests}

The authors declare that there are no conflicts of interest related to this article.

\section{References}

Aghighi Shahverdi M, Omidi H, Tabatabaei SJ (2017). Effect of nutri-priming on germination indices and physiological characteristics of stevia seedling under salinity stress. Journal of Seed Science 39(4):353-362.

Aghighi Shahverdi M, Omidi H, Tabatabaei SJ (2019). Stevia (Stevia rebaudiana Bertoni) responses to $\mathrm{NaCl}$ stress: Growth, photosynthetic pigments, diterpene glycosides and ion content in root and shoot. Journal of the Saudi Society of Agricultural Sciences 18:355-360.

Andrzejewska J, Sadowska K, Mielcarek S (2011). Effect of sowing date and rate on the yield and flavolignan content of the fruits of milk thistle (Silybum marianum L. Gaertn.) on light soil in a moderate climate. Industrial Crops and Products 33:462468.

Anusuya S, Banu KN (2016). Silver-chitosan nanoparticles induced biochemical variations of chickpea (Cicer arietinum L.). Biocatalysis and Agricultural Biotechnology 8:39-44.

Bates L, Waldren R, Teare I (1973). Rapid determination of free proline for water-stress studies. Plant and Soil 39:205-207.

Beauchamp C, Fridovich I (1971). Superoxide dismutase: Improved assays and an assay applicable to acrylamide gels. Analytical Biochemistry 44:276-287.

Burguieres E, McCue P, Kwon YI, Shetty K (2007). Effect of vitamin C and folic acid on seed vigor response and phenolic-linked antioxidant activity. Bioresource Technology 98:1393-1404.

Cha-Um S, Kirdmanee C (2009). Effect of salt stress on proline accumulation, photosynthetic ability and growth characters in two maize cultivars. Pakistan Journal of Botany 41:87-98.

Demidchik V (2015). Mechanisms of oxidative stress in plants: from classical chemistry to cell biology. Environmental and Experimental Botany 109:212-228.

Dolatabadian A, Modares Sanavy SAM, Chashmi NA (2008). The effects of foliar application of ascorbic acid (Vitamin C) on antioxidant enzymes activities, lipid peroxidation and proline accumulation of canola (Brassica napus L.) under conditions of salt stress. Journal of Agronomy and Crop Science 194:206-213.

El-Keblawy A, Al-Rawai A (2005). Effects of seed maturation time and dry storage on light and temperature requirements during germination in invasive Prosopis juliflora. Flora 201:135-143.

El-Miniawy SM, Ragab ME, Youssef SM, Metwally AA (2013). Response of strawberry plants to foliar spraying of chitosan. Research Journal of Agriculture and Biological Science 9(6):366-372.

Farooq M, Hussain M, Wakeel A, Siddique KHM (2015). Salt stress in maize: Effects, resistance mechanisms, and management. A review. Agronomy for Sustainable Development 35:461-481.

Farooq M, Wahid A, Kobayashi N, Fujita D, Basra SMA (2009). Plant drought stress: Effects, mechanisms, and management. In: Lichtfouse E, Navarrete M, Debaeke P, Véronique S, Alberola C (Eds). Sustainable Agriculture. Springer, Dordrecht, pp 153-188.

Ferreira T, Pavia I, Baltazar M, Rocha L, Pereira JM, Lima-Brito J, Correia C (2016). Vitamin B6 ameliorates germination and early growth of Triticum durum L. under water stress conditions. 24th International Symposium of the International Scientific Centre of Fertilizers. Coimbra (Portugal), September 6-8, 2016.

Genuchten MTh van (1983). Analysing crop salt tolerance data: model description and user's manual. Research Report No. 120. U.S. Salinity Laboratory, USDA-ARS, Riverside, California. 
232

Ghavami N, Ramin AA (2007). Salinity and temperature effects on seed germination of Milk thistle. Communications in Soil Science and Plant Analysis 38:2681-2691.

Ghoulam C, Fares K (2001). Effect of salinity on seed germination and seedling growth of sugar beet (Beta vulgaris L.). Seed Science and Technology 29:357-364.

Gornik K, Grzeisk B, Duda R (2008). The effect of chitosan on rooting of grapevine cuttings and on subsequent plant growth under drought and temperature stress. Journal of Fruit Ornamental Plant Research 16:333-343.

Gorzi A, Omidi H, Bostani AB (2018). Morpho-physiological responses of stevia (Stevia rebaudiana Bertoni) to various priming treatments under drought stress. Applied Ecology and Environmental Research 16(4):4753-4771.

Guan YJ, Hu J, Wang XJ, Shao CX (2009). Seed priming with chitosan improves maize germination and seedling growth in relation to physiological changes under low-temperature stress. Journal of Zhejiang University Science B 10(6):427-433.

Hameed A, Sheikh MA, Hameed A, Farooq T, Basra SMA, Jamil A (2014). Chitosan seed priming improves seed germination and seedling growth in Wheat (Triticum aestivum L.) under osmotic stress induced by polyethylene glycol. Philippine Agricultural Scientist 97(3):294-299.

Harish P, Dharmesh MS, Jagannatha Rao KS, Tharanatha RN (2007). Free radical-induced chitosan depolymerized products protect calf thymus DNA from oxidative damage. Carbohydrate Research 342(2):190-195.

Imran M, Bolet B, Muhling KH (2018). Zinc seed priming improves salt resistance in maize. Journal of Agronomy and Crop Science 1-10.

ISTA (2009). Workshop reports - ISTA online - International seed testing Association.

Kar M, Mishra D (1976). Catalase, peroxidase and polyphenol oxidase activity during rice leaf senescence. Plant Physiology 57:315-319.

Karkanis A, Bilalis D, Efthmiadou A (2011). Cultivation of milk thistle (Silybum marianum L. Gaertn.), a medicinal weed. Industrial Crops and Products 34:825-830.

Keshavarz H, Moghadam RSG (2017). Seed priming with cobalamin (vitamin B12) provides significant protection against salinity stress in the common bean. Rhizosphere 3:143-149.

Lauchli A, Luttge U (2012). Salinity: environment plants molecules. the Netherlands: Springer.

Lehmann S, Funck D, Szabados L, Rentsch D (2010). Proline metabolism and transport in plant development. Amino Acids 39(4):949-962.

Lichtenthaler HK (1987). Chlorophylls and carotenoids. Pigments of photosynthetic membranes. Method Enzyme 148:350382.

Lipiec J, Doussan C, Nosalewicz A, Kondracka K (2013). Effect of drought and heat stresses on plant growth and yield: a review. International Agrophysics 27(4):463-477.

Misra N, Dwivedi UN (2004). Genotype differences in salinity tolerance of green gram cultivars. Plant Science 166:1135-1142.

Nasiri Y, Feyzi P, Javanmard A (2014). Effects of hydro and hormonal seed priming on seed germination of milk thistle under saline stress condition. Notulae Scientia Biologicae 6(3):374-380.

Parmoon G, Ebadi A, Jahanbakhsh S, Moosav SA (2015). Effects of seed priming on catalase activity and storage reservoirs of aged milk thistle seeds (Silybum marianum (L.) Gaertn). Journal of Agriculture Sciences 21:363-372.

Pongprayoon W, Roytrakul S, Pichayangkura R, Chadchawan S (2013). The role of hydrogen peroxide in chitosan-induced resistance to osmotic stress in rice (Oryza sativa L.). Plant Growth Regulation 70(2):159-173.

Qu C, Liu C, Gong X, Li C, Hong M, Wang L, Hong F (2012). Impairment of maize seedling photosynthesis caused by a combination of potassium deficiency and salt stress. Environmental and Experimental Botany 75:134-141.

Raschke M, Boycheva S, Crevecoeur M, Nunes-Nesi A, Witt S, Fernie AR, ... Fitzpatrick TB (2011). Enhanced levels of vitamin B6 increase aerial organ size and positively affect stress tolerance in Arabidopsis. The Plant Journal 66:414-432.

Rosinska A, Dorna H, Szopinska D, Irzykowska L, Seidler-Lozykowska K (2018). Evaluation of milk thistle (Silybum marianum (L.) Gaertn.) seed germination in relation to seed health and seedling emergence. Herba Polonica 64(3):1-10.

Sadeghi H, Khazaei F, Yari L, Sheidaei S (2011). Effect of seed osmo-priming on seed germination behavior and vigor of soybean (Glycine max L.). ARPN Journal of Agriculture and Biological Science 6(1):39-43.

Sedghi M, Nemati A, Amanpour-Balanji B, Gholipouri A (2010). Influence of different priming materials on germination and seedling establishment of milk thistle (Silybum marianum) under salinity stress. World Applied Sciences Journal 11(5):604-609. 
Sharma P, Jha AB, Dubey RS, Pessarakli M (2012). Reactive oxygen species, oxidative damage, and antioxidative defense mechanism in plants under stressful conditions. Journal of Botany 12:1-26.

Sheikha SAAK, AL-Malki FM (2011). Growth and chlorophyll responses of bean plants to the chitosan application. European Journal of Scientific Research 50(1):124-134.

Suchada B, Sarobol E, Meechoui S, Sooksathan I (2007). Drought recovery and grain yield potential of rice after chitosan application. Kasetsart Journal (Natural Science) 41:1-6.

Sudhakar C, Lakshmi A, Giridara KS (2001). Changes in the antioxidant enzyme efficacy in two high yielding genotypes of mulberry (Mours alba L.) under NaCl salinity. Plant Science 167:613-619.

Sultana S, Islam M, Khatun MA, Hassain MA, Huque R (2017). Effect of foliar application of oligo-chitosan on growth, yield and quality of tomato and eggplant. Asian Journal of Agricultural Research 11(2):36-42.

Teresa BF (2011). Vitamins B6 in plants: more than meets the eye. Advances in Botanical Research 59:1-38.

Van Genuchtan MT, Hoffman GJ (1984). Analysis of crop salt tolerance data. Soil salinity under irrigation-process and management. Ecological Studies 51:258-271.

Verma S, Mishra SN (2005). Putrescine alleviation of growth in salt-stressed Brassica juncea by inducing antioxidative defense system. Journal of Plant Physiology 162:669-677.

Walker-Simmons M, Ryan CA (1984). Proteinase inhibitor synthesis in tomato leaves: induction by chitosan oligomers and chemically modified chitosan and chitin. Plant Physiology 76(3):787-790.

Yin H, Bai XF, Du YG (2008). The primary study of oligochitosan inducing resistance to Sclerotinia sclerotiorum on B. napus. Journal of Biotechnology 136:600-601.

Yin H, Xavier CF, Chrestensen LP, Grevsen K (2011). Chitosan oligosaccharides promote the content of polyphenols in Greek oregano (Oregamum vulgare ssp. Hirtum). Journal of Agricultural and Food Chemistry 60(1):136-143.

OPEN ACCESS

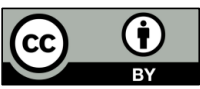

The journal offers free, immediate, and unrestricted access to peer-reviewed research and scholarly work. Users are allowed to read, download, copy, distribute, print, search, or link to the full texts of the articles, or use them for any other lawful purpose, without asking prior permission from the publisher or the author.

License - Papers published in Notulae Botanicae Horti Agrobotanici Cluj-Napoca are Open-Access, distributed under the terms and conditions of the Creative Commons Attribution (CC BY) License.

(c) Articles by the authors; UASVM, Cluj-Napoca, Romania. The journal allows the author(s) to hold the copyright/to retain publishing rights without restriction. 